\title{
An Analysis of the Emergence, Development and Doctrines of the Mu'tazilites in The Light of Islamic Perspectives
}

\author{
Zayyanu Altine $^{1 *}$, Adam Yusuf Adam² \\ ${ }^{1}$ Postgraduate Student, Faculty of Arts and Islamic Studies, Department of Islamic Studies, Usmanu Danfodiyo University, Sokoto, \\ Nigeria \\ ${ }^{2}$ Faculty of Arts and Islamic Studies, Department of Islamic Studies, Usmanu Danfodiyo University, Sokoto, Nigeria
}

\section{${ }^{*}$ Corresponding Author \\ Zayyanu Altine}

\section{Article History}

Received: 10.07.2019

Accepted: 25.07 .2019

Published: 30.07 .2019

\begin{abstract}
Mu'tazila is one of the theologian schools of thought of the Muslims. They got originated in the eighth century Hijri when a student Wasil bin Ata made differences on some Islamic issues with his teacher Al-Hassan Al-Basri. The differentiating point between the two was; what will be the position of a person after committing a major sin? He/ She will be Muslim or not? Wasil bin Ata was of the view that such a person will be in an intermediate position neither (Neither Muslim nor non-Muslim) and he called him ( $\mathrm{Al}$ Manzila Bayn Al-Manzilatain). This was a new idea and terminology presented by Wasil bin Ata for the first time. This article discusses the position of Mu'tazilah as, their major doctrines and the differences with the basic Islamic believes and their effects on Muslim society. Also the paper will discuss the minor doctrines Mu'tazilah such as rejecting of vision Allah in the day of resuscitation, creation of the Glorious Qur'an, Good and Evil among others. Furthermore, the paper highlights on the unity of Muslims as a Unity of Muslims as a Prerequisite for Successful Islamic Civilisation, aims of unity in the Muslim Ummah, Reasons for this unity among the Muslims, and remedies on how to achieve unity in the Muslim Ummah.
\end{abstract}

Keywords: Emergence, Development, Doctrines, Mu'tazilites, and Islamic teachings

\section{INTRODUCTION}

Islamic political movements might have impacted the theological thoughts, dimensions and ideologies of Islamic sects. After the death of Prophet Mohammed, Muslim people tried to find a government system and started to discuss with each other about the leadership of Muslims. Who will be the leader of Muslims and how they will choose him raised and caused a controversial issue among them. The discussion between the Muhājirun and the Ansār did not cause a big division among early Muslims. However, after the battles of the Camel and Siffinn, Muslims divided into several sects, the Shi'ah, the Khawārij and the Murji'ah.

Especially, the leadership position of the fourth caliph, 'Ali, was questioned and turned into political and theological debates [1]. In addition, from the earliest time, the rationalist movement became an outstanding dimension of Muslim theology. In spite of the fact that rationalism faced some scathing critique from its antagonist throughout Islamic history, it remained the main basis of Muslim theological ideas and concepts. One of the most essential and effective rationalist groups in the history of Islam based on reason was the Mu'tazilite. This sect has an important and central place in Islamic theology because it influenced the later Islamic theology directly or indirectly and they were the first representatives of the science of Kalām [2].

\section{Definition of Mu'tazilah}

The word Mu'tazilah is derived from Arabic word I'tizal which means to withdraw or secede. Mu'tazilites are the people who in some of their beliefs were diametrically opposed to the unanimous consent of the early and present theologians or the People of the Approved Way (ahl Al-Sunnah).

The leader of all of them was Wasil bin 'Ata who was born in 80 A.H/699 C.E at Madinah and died in 131 A.H/748 C.E. Because of his over emphasis on reason on certain issues of Islamic thought his teacher Imam Hasan Basri said to him, "I'tazala

Copyright @ 2019: This is an open-access article distributed under the terms of the Creative Commons Attribution license which permits unrestricted use, distribution, and reproduction in any medium for non commercial use (NonCommercial, or CC-BY-NC) provided the original author and source are credited. 
'anna," i.e., "He has withdrawn from us." Therefore, Wasil and his followers were called al-Mu'tazilah, the Withdrawers or Secessionists [3]. Therefore, Mu'tazilah literally means 'those who withdraw themselves'.

A theological dispute aroused on the subject of the Intermediate Position (Al-Manzila Bayan al-Manzilatayan); after committing a major sin. Thus, he along with his followers, including Amr bin Ubaid, were named as Mu'tazili. Later on they named themselves as Ahal-Tawhid Wal-adal centered on their preaching, which was to ground in reason the Islamic creedal system.

\title{
The Emergence and Development of Mu'tazilism
}

The Mu'tazilite was the earliest rationalist school in Islamic theology. The fact that it emerged in 720 is said to be because of the connection with its doctrine of the status of the sinner the roots of which are in the Umayyad time, but it did not show a big influence until 800 (Patricia Crone, n.d). Dhanani points out that the beginning of the Mu'tazilite movement is connected with this parathion of Wāsil bn Atā (d. 748) and Amr bn Ubayd (d.761) (Patricia Crone, n.d) from the circle of al-Hasan al-Basrī (d. 728) due to their disagreement on the position of a great sinner. The response to this question was that whether the sinful Muslim is a believer (mu'min) or an unbeliever (kāfir) was that the sinful Muslim should be into an intermediate status between mu'min and kāfir [20].

Mu'tazili arose over an extended span of time, like all other schools. Abu Al-Hudhayl Al-Allaf, came after Wasil bn 'Amr bn Ubayd and is thought to be the theologian who organized and systematized Mu'tazilism in Basra [6]. While Bishr bn al Mu'tamir organized another branch of the school in Baghdad.

Theologians lost much of the importance as a consequence of reaction against rationalism and increase in the number of Muslims throughout the world. The issue was further aggravated by the Minha, inquisition initiated under the Abbasyeds Caliph AlMa'mun. Mu'tazilites were indicted of being the provokers nonetheless the scheme was of Caliph's himself [4]. The atrocity drive, anyhow, charged them and theology, generally, the support of the Muslim people.

In the 9th century, Mu'tazilites was compelled for violence and secondly the non-believers, deists, scholars and non-Muslim philosophers also pressed them. The opponents also worked with rational approach. Both worked with reasons.

One of the most essential and effective rationalist groups in the history of Islam based on reason was the Mu'tazilite. This sect has an important and central place in Islamic theology because it influenced the later Islamic theology directly or indirectly and they were the first representatives of the science of Kalām.

Due to the persistent assaults, the theologians of Mu'tazilites presented their ideas in a systematic way. Abu Ali Al-Jubbai led this mission in Basra although there were some differences among them on some issues. In the late tenth and early eleventh century Abdul Jabbar was prominent figure and because of this struggle many doctrines and methodologies of the school remained alive [4].

\section{There are five major Doctrines/tenets of Mu'tazilah}

There are five principal doctrines which, according to the Mu'tazilah themselves, constitute their basic tenets.

\author{
Al-Tawheed (Divine Unity) \\ Mu'tazili strongly believes in Al-Tawheed, the unquestionable unity and oneness of Allah [5]."
}

The doctrine of Tawhid, according to Mu'tazilah well known scholar Chief Justice Abdul Jabbar Ibn Ahmad, in a real Mu'tazilah book which was translated in by Martin et al. [6]: it is the realization that Allah is matchless, and has qualities not shared by any creature. This is realized by the truth that this world has a Maker (san'i) who created it and is eternal and Almighty (qaadir) and that powerlessness (al-ijz) is out of possibility. He is all-knowing of the bygone, present and future and that (jahl) ignorance is impossible for Him. He is all-knowing of what was, is, and will be. He is eternity who was present in the past and will be present in the future (hay'y), and any misfortune and worries are not meant for Him. He witnesses the obvious (mar'iyat) and comprehends perceptible, and has no need of sense organs. He is sufficient in future and was sufficient in past (ghani) [5]. He has no physical body and no qualities of rest, color, movement, change, getting down or up, having form, being composite, and having form, limbs and other parts, eating anything or smelling things. Everything, other than Him, is dependent, and created. When a person knows all this, he/she knows Allah's oneness.

\section{Justice of Allah (al-Ad)}

The most important and basic doctrine of Mu'tazila was Justice of Allah and the will of Allah to do only good for His people. Ashari school of thought believed that Allah was above all rules and laws, because rules and laws were only for human beings. Allah does what He wants. Contrary to this, the Mu'tazila put forward the idea that Allah is bound by some rules. It would be injustice on the part of Allah if He does not obey the rules made by Him. Mu'tazila argued that it would be injustice of Allah if He has already predetermined all actions of human beings. Again, according to Mu'tazila, it would be justice of Allah to leave his people to become believer or unbeliever. Allah only does well for His creation because Allah is just. If Allah does anything evil, it would be against His 
Justice. It is the justice of Allah to demand from his people according to their capacity [3]. According to Mu'tazila, there would be no use of any judgment of good and evil actions of humanity if things are already shaped and consequently, there would be no use of giving reward and punishment on the Day of Judgment on the basis of human effort.

\section{The Promise and the Threat (Al-Wa'd Wa 'L-Waid)}

The third point of Mu'tazila theological doctrine was more or less part of the second point, i.e. Justice of Allah. The Mu'tazila believed that human beings would be rewarded or punished on the ground of their good or bad actions.

They believed that it would be injustice to make Allah responsible for the wrong-doings and sins of human beings. Allah is wise so Allah does only that is good and just for humanity [7]. Only those who deserve Allah's reward would be rewarded and those who deserve His punishment would be punished. There is no doubt that Allah has the ability to pardon and punish but according to Mu'tazila, the punishment or reward by the Allah Almighty would be on merit.

\section{The Intermediate Position (Al-Manzila bayn al-Manzilatayn)}

The most important question that gave emergence to the Mu'tazila school of thought was the question about the status of the grave sinner. Kharijis believed that grave sinner was unbeliever, i.e. kafir and would be in the Hell forever, while Murjia were of the opinion that the grave sinner was a Muslim but he would be punished for his or her sin after the death. The Mu'tazila adopted the middle way about the status of grave sinner. They were of the opinion that the grave sinner was a fasiq, i.e. an intermediate rank between a believer and non-believer [7].

\section{Command the Good and Forbid the Evil (Amr Bil Maruf Wa Nahi an Al-Munkar)}

Among the essentials of Islam, one of the important points is enjoining good and forbidding from evil. This point is also one of the five doctrinal points of Mu'tazila. They argued that it was not just Sharia law which defined good and evil but human being was capable through his reasoning ability to differentiate between good and evil. This point was important in respect of the involvement of Muslims in the state affairs. Mu'tazila themselves participated in the religious and political debates of that age. They backed the mihna [8] or inquisition of al-Mamun to force the 'Ulama to accept the doctrine of createdness of the Quran.

Mu'tazila theological doctrines were based on rationalism. They tried to interpret Allah, Islamic beliefs and practices and the questions of reward and punishment after death on rational and philosophical grounds. They fell under the banner of heresy during the time of Caliph Mutawakkil because they did not recognize the prevailing theological interpretations of the traditional 'Ulama.

\section{Another minor Doctrines of Mu'tazilites}

\section{Good and Evil}

Mu'tazilites believes that "things are not good or evil because Allah declares them to be so. No, Allah makes the distinction between good and evil on account of their being good and evil. Goodness or evil are innate in the essence of things themselves [3]". They maintain that Allah is good and just, and that evil and injustice should not be referred to Him. If Allah creates evil He should be evil, and if He creates justice, then He would be just. But as Allah is absolutely good and just, evil and injustice cannot be attributed to $\operatorname{Him}[6]$.

This very goodness or evil of things is the cause of the commands and prohibitions of the Law. The human intellect is capable of perceiving the goodness and evil of a few things and no laws are required to express their goodness and evil, e. g., it is commendable to speak the truth and despicable to commit oneself to untruth. This shows that the evil and goodness of things are obvious and require no proof from the Shari ah. Shameful and unjust deeds are evil-in-themselves; therefore, Allah has banned indulgence in them. It does not imply that His putting a ban on them made them shameful and unjust deeds.

\section{The Creation of Qur'an}

All Mu'tazilah concurred that Qur'an is a creature and updated, the Judge Abdul Jabbar agreed that Al Mu'tazilah doctrine, he said: "and it is a creature and updated" [3]. They had inferred for their saying by several evidences the main of them the Allah Almighty saying (Allah is the creator of everything) [3]. they said the verse means everything, the general, whereas Qur'an is a thing, so it is entering in generalization (ALL) so it will be a creature, so there is no evidence to exclude Qur'an from the generalization, so it must enter the whole.

\section{Denial of the Vision of Allah in the Hereafter}

From the foundations of Al Mu'tazilah doctrine, the vision of Allah should be denied, and who does not believe that is disbeliever as the point view. The Judge Abdul Jabbar said: "The vision by eyesight for Allah is impossible, and what should be denied is the vision [9]". Their main inferred the Allah's say (No vision can grasp Him, but His grasps is over all vision. He is above all comprehension, yet is acquainted with all things) [10]. 


\section{Free Will}

The Mu'tazilites accepted totally the theory of indeterminism and became true successors of the Qadarites [3]. They address the question of free will and determinism, and they decided in favor of free will, and attributed to creatures the power to carry out their own acts. They argued that if humans did not have the power to choose and create their own acts, there would be no point to the rewards and punishments promised by Allah to humans in the next life. They claimed that Allah was a just Allah and that it was inconceivable that Allah would reward or punish humans for acts over which they had no power or control [11].

\section{Unity of Muslims as a Prerequisite for Successful Islamic Civilisation}

Glorious Islamic teachings are manifest to foster the unity and consciousness of the Muslim Ummah. All the ignoble elements which are aspirant to disunite the Muslim Ummah have been repudiated and reviled. Islam has gathered all the Muslims together in a string of fraternity and has taught to desist from conflicts and clashes which reprehensibly affect unity.

\section{Meaning of Unity \\ Imam Raghib Isfahani (Died in 502 Hijri) writes:}

"Unity means "Al-infarad" that is to say the unique and distinctive and one, in fact it is called about that particular thing which has no part [12]".

And the substance of the word "Tauhid" it means belief in Oneness of Allah regarding His existence and all Attributes [6]".

\section{The Injunctions of the Glorious Qur'an Regarding Unity of Ummah}

"Surely, this is the fraternity of your Faith, a single Faith, and I am your Lord; so worship Me" (Qur'an: 92).

\section{And Imam Hassan al-Basri (R.A.) writes}

"Your method is one that is to say this Shari'ah which has been mentioned that is agreed upon Shariah [14]".

\section{Ibne Jareer Tabri (Died in 310 Hijri) writes to define this verse}

"Doubtlessly your nation is only one nation and I am your Lord O people, worship Me, besides other idols and gods whom you worship except Me [13]."

\section{In another verse Allah says}

And in another verse Allah says:

"Surly, this is your creed, a single creed, and I am your Lord. So fear Me (Qur'an: 52)".

"All men used to be a single „Ummah (i.e. on a single faith). Then (after they differed in the matters of faith), Allah sent Prophets carrying good news and warning, and sent down with them the book with Truth to judge between people in the matters of their dispute (Qur'an: 213)"

It was comprehensible that despite contradistinctions of era and areas of the Prophets (A. S.) they all unanimously followed one belief and one religion and that is the invitation to believe in One Allah about which every Prophet (A. S.) called his respective community.

\section{Sayings of Prophet Muhammad (Blessings and peace be upon him) about unity}

Prophet Muhammad (Blessings and peace be upon him) said

O people! Your Lord is one and your father is also one; remember there is no superiority for an Arab over a Non-Arab and for a Non-Arab over an Arab, neither for the white over the black nor for the black over a white except in Allah-consciousness [15].

In another Hadith While delivering a lesson to accentuate unity among the Muslims, Prophet Muhammad (SAW) said: A Muslim is a brother of another Muslim, so he should not maltreat him, nor should he hand him over to a tormentor. Whosoever fulfilled the needs of his brother, Allah will fulfill his needs; whosoever brought his (Muslim) brother out of tribulation, Allah will bring him out of afflictions of the Day of Resurrection, and whosoever screened a Muslim, Allah will screen him on the Day of Resurrection (Al-Bukhari).

If all the members of Muslim Ummah start following the footsteps of the model of excellence, the Glorious Prophet (P.B.U.H) and decide to fulfill the rights of the Glorious Prophet (Blessings and peace be upon him) resultantly they all will be able to achieve 
crowning glory and this will be the golden age of the Muslim unity and solidarity. Ultimately despise and disdain among the Muslims will be eliminated.

Similarly while describing the nature of relationship of one Muslim with another Muslim, the Prophet (Blessings and peace be upon him) said:

A true believer to a sincere believer is like the brick of a wall, strengthening each other, while (describing that) the Glorious Prophet (Blessings and peace be upon him) clasped his hands by interlacing his fingers (Al-Bukhari).

While describing the blessings and rewards of unity of the Muslims, the Prophet (Blessings and peace be upon him) said:

"And the hand of Allah is on the Jama'ah (group) and whosoever breaks from it, is immersed into the fire (Tirmidhi)".

These AHadiths are highlighting the Muslim Unity substantially and comprehensively. And these teachings had gathered all the Muslims in a string of unity despite different color and ancestry, language, family and regardless of being from different areas.

\section{Aims of Unity among the Muslim Ummah}

Said Nursi placed a great importance on determining the correct objective of unity of Muslims. According to him, a common goal is the main element around which all religious groups and societies should be united [16]. In an article entitled The Voice of Truth Nursi defined the goal of unity as follows: "The aim and goal of unity is to stir into life the long, many branched, far-reaching luminous chain which binds together the centres of Islam and their places of worship, to arouse those bounds to it, and through the wishes and promptings of their consciences drive them to the way of progress [16]."

Nursi said: "Our aim now is to urge everyone toward the ka'ba of achievement and perfections on the way of progress with an eagerness and desire of the conscience through making that luminous chain vibrate. For at this time the most powerful means of upholding the World of Allah is through material progress [17]".

\section{Reasons for Disunity among the Muslim Ummah}

Despite the fact that Nursi considered Western imperialism to be responsible for disturbing Islamic unity, he believed that the main role in the loss of concord and harmony among Muslims was played by internal factors. In 1909 Nursi remarked that the heart disease of the Osmanli nation was their weakness in religion [16]. In his article entitled Long Live the Shari’ah of Muhammad, Nursi called upon the newly established CUP government that if they want success, they should conform to the Divine laws. Otherwise they would be unsuccessful. The intellectual furthermore stated that for the fact that all the known prophets appeared in the lands of Islam and the Ottomans is a sign of Divine Determining that the steam of the engine of the progress of this country's people is religion. The flowers of these fields of Asia, Africa, and Rumelia will grow and flourish through the light of Islam [16].

Accordingly, Said Nursi believed that the main reason behind contemporary disunity of Muslims, and various number of calamities in their political, religious, moral-ethical and social spheres is related to internal factors, which are carelessness, irreligiousness and ignorance of the political and spiritual leadership, and the entire Muslim community.

Nursi blamed the community of Muslims for their heedlessness toward teachings of the Qur'an. In Sünūhāt, Nursi stated that "the most important cause of the Islamic community displaying carelessness and negligence toward the precepts of religion [18]". Besides the absence of true belief in the hearts of Muslims, Nursi in The Damascus Sermon detected another six sicknesses present among Muslims, what kept them disunited, backward and ignorant, and have arrested the development of the Islamic world. The sicknesses are as follows:

Firstly, the coming to life and rise of despair and hopelessness in social life. Secondly, the death of truthfulness in social and political life. Thirdly, love of enmity. Fourthly, not knowing the luminous bonds that bind the believers to one another. Fifthly, despotism, which spreads like various contagious diseases. And sixthly, restricting endeavour to what is personally beneficial [16].

Another causes of disunity among the Muslim Ummah is intolerance towards one another, one of the characteristics of the Ummah today, is our aggressive attitude towards each other, coupled with the habit of seeking faults in the Muslims around us, while turning blind eyes to our own his faults [19].

Selfish Transgression (Envy)-In an authentic Hadith, the Prophet (peace be upon him) emphasized that envy and hatred is the main reasons for division of this Ummah as well as to the previous one says He (peace be upon him): 
Among you spread the disease of previous nations; it is the envy and hatred. It is what I call the shaver which wipes out your Deen the same way the shaver shaves hair (Timidhi).

Envy, is one of the harmful diseases of the heart, spreads between Muslims, dividing their hearts and making them hate one another.

\section{Six Remedies in Achieving Unity in the Muslim Ummah}

Nursi in his Damascus Sermon determined six dire sicknesses present among Muslims, what kept them disunited, backward and ignorant, and arrested the development of the Islamic world: firstly, rise of despair and hopelessness in social life; secondly, the death of truthfulness in social and political life; thirdly, love of enmity; fourthly, not knowing the luminous bonds that bind the believers to one another; fifthly, despotism, and sixthly, restricting endeavour to what is personally beneficial [16].

Nursi identified these sicknesses as destroyers of Islamic unity. Only elimination of these sicknesses can reunite Muslims as Nursi hoped that "Insha Allah.

\section{CONCLUSION}

From the above discussion we can conclude that there is scope of rationality in Islam. And the Mutazilites are believed to be the pioneer of rationality in Islam. Muslims generally speak of Wasil's party as the Mu'tazilites, but they latter call themselves People of Unity and Justice (ahl al-tauhid wal 'adl). By justice they imply that it is incumbent on Allah to requite the obedient for their good deeds and punish the sinners for their misdeeds. By unity they imply the denial of the divine attributes. Unity and justice are the basic principles of the beliefs of the Mu'tazilites and this is the reason why they call themselves "People of Unity and Justice."

Islam is greatest proponent religion of the Muslim Unity. By studying and following the injunctions of the Glorious Qur'an, Sunnah and event of the life of companions (R.A.) of the Prophet (peace be upon him) it is known that Islam attaches particular importance to the unity of the Muslim Ummah. The Prophet (peace be upon him) has strongly condemned and discouraged such persons or groups who try to disunite and dissociate the Muslims by subterfuge or intrigue.

\section{REFERENCES}

1. Watt, W. M. (2002). The formative period of Islamic thought: Oneworld classics in religious studies.

2. Saeed, A. (2006). Islamic thought: An introduction. Routledge.

3. Sharif, M. M. (1963). A History of Muslim Philosophy, Kempten, Germany, Allgauer Heimatverlag GmbH.

4. Nawas, J. A. (1994). A Reexamination of Three Current Explanations for al-Ma'mun's Introduction of the Mihna. International Journal of Middle East Studies, 26(4), 615-629.

5. Qazi, A. (1996). Al-Mutazila and Their Five Princples, Maktaba Wahab, Riadh, Saudi Arabia.

6. Jabbar, Abd al. (1997). 'Kitab al-Usul al-Khamsa' in Defenders of Reason in Islam, Richard C Martin and others, Oneword, Oxford. Keranavi, Waheed-uz-Zaman, Al-Qamoos UI-Waheed, Lahore, Idara Islamiyat, 1821

7. Shahrastani, M. A. (1984). Kitab al-milal wa al-nihal, Muslim Sects and Divisions tr. A.K. Kazi and J.G. Flynn. London: Kegan Paul.

8. Berkey, J. P. (2002). The formation of Islam: Religion and society in the Near East, 600-1800 (Vol. 2). Cambridge University Press.

9. Stepaniants, M. (2002). Introduction to Eastern Thought, tr. Romella Kohanovskaya. Lanham: Rowman and Little field.

10. Deen, S. M. (2007). Science under Islam: rise, decline and revival. Lulu. com.

11. Khan, D. T. Mutazilaism: An Introduction to Rationality in Islam. International Journal of Engineering and Applied Sciences, 4(10).

12. Al-Isfahani, A. A. M. (1412). Al-Mufradat Fee Graib-ul-Quran, Beirut, Dar-e- Alqalam, (1),".

13. Al-Tabri, M. J. (1420). Abu Jaffar, Jamay Al-Bayan Fee Taveel Al-Qur'an, Maossata Al Rassalatah, 18.

14. Ibn-e-Kaseer, I. U, A. Tafseer-ul-Quran-el-Azeem, Beirut, Dar-Al-kitab-Al-Elamiya, 1419 Hijri, 5.

15. Ahmed B. H. (1421), Al Musnad, Maossata Ul-Resalatah, 38.

16. Nursi. S. (2002a). The Damascus Sermon. (2nd edn.). (Ş. Vahide, Trans.). Istanbul: Sözler Publications. (Original work published 1911).

17. Vahide, Ş. (1998). Bediuzzaman Said Nursi: The author of the Risale-i Nur. Turkey: Sözler Publications.

18. Berghout, A. (2005, August). The concept of iman tahqiqi as a founding element to the process of Muslim unity (Ustaz Nursi's View). Paper presented at the 2-Day Seminar on Bediuzzaman Said Nursi: A contemporary approach to realizing Muslim unity, International Islamic University of Malaysia, Kuala Lumpur.

19. Hauwau, B. \& Abdulrazaq, B. O. (2013). Challenges of the contemporary Muslims: An exposition on their Nature, Effects and Solution, (n.p), Sahaabah Publications. Muhammad, A.I. (n.d.), Al-Jami al-Tirmidhi, A. Al-Sababity (ed.), vol. 7 Daral-Hadith al Qahirah.

20. Patricia Crone, (n.d), Allah's Rule Govemmentand Islam: Six Centuries of Medieval Islamic Thought (New York: Columbia University Press). 